\title{
Chemical composition and evaluation of antileishmanial and cytotoxic activities of the essential oil from leaves of Cryptocarya aschersoniana Mez. (Lauraceae Juss.)
}

\author{
PRISCILA M. DE ANDRADE ${ }^{1}$, DAIANA C. DE MELO ${ }^{1}$, ANA ELISA T. ALCOBA ${ }^{1}$, WALNIR G. \\ FERREIRA JÚNIOR ${ }^{2}$, MARIANA C. PAGOTTI ${ }^{3}$, LIZANDRA G. MAGALHÃES ${ }^{3}$, TAINÁ C.L. DOS \\ SANTOS $^{4}$, ANTÔNIO E.M. CROTTI ${ }^{4}$, CASSIA C.F. ALVES ${ }^{5}$ and MAYKER L.D. MIRANDA ${ }^{6}$
}

\author{
${ }^{1}$ Instituto Federal de Educação, Ciência e Tecnologia do Sul de Minas Gerais, Campus Pouso Alegre, \\ Av. Maria da Conceição Santos, 900, Parque Real, 37550-000 Pouso Alegre, MG, Brazil \\ ${ }^{2}$ Instituto Federal de Educação, Ciência e Tecnologia do Sul de Minas Gerais, Campus Machado, \\ Rod. Machado-Paraguaçu, s/n, Santo Antônio, 37750-000 Machado, MG, Brazil \\ ${ }^{3}$ Centro de Pesquisa em Ciências Exatas e Tecnologia, Universidade de Franca, Av. Dr. Armando \\ de Salles Oliveira, 201, Parque Universitário, 14404-600 Franca, SP, Brazil \\ ${ }^{4}$ Departamento de Química, Faculdade de Filosofia, Ciências e Letras de Ribeirão Preto, Universidade \\ de São Paulo, Av. Bandeirantes, 3900, Monte Alegre, 14049-900 Ribeirão Preto, SP, Brazil \\ ${ }^{5}$ Instituto Federal de Educação, Ciência e Tecnologia Goiano, Campus Rio Verde, \\ Av. Sul Goiana, s/n, Zona Rural, 75901-970 Rio Verde, GO, Brazil \\ ${ }^{6}$ Instituto Federal de Educação, Ciência e Tecnologia do Triângulo Mineiro, Campus Uberlândia \\ Centro, Rua Blanche Galassi, 150, Morada da Colina, 38411-104 Uberlândia, MG, Brazil
}

Manuscript received on May 8, 2017; accepted for publication on August 15, 2017

\begin{abstract}
Leishmaniasis is an endemic disease caused by protozoa of the genus Leishmania, which affects around two million people worldwide. One major drawback in the treatment of leishmaniasis is the emergence of resistance to current chemotherapeutics. Medicinal and aromatic plants constitute a major source of natural organic compounds. In this study, the leaf essential oil of Cryptocarya aschersoniana was obtained by hydrodistillation in a Clevenger-type apparatus, and the chemical composition was analyzed by GC-MS and GC-FID. The essential oil of these species was predominantly constituted by monoterpene hydrocarbons (48.8\%). Limonene (42.3\%), linalool (9.7\%) and nerolidol (8.6\%) were the main constituents in the oil of $C$. aschersoniana. The in vitro activity of the oil was evaluated against the promastigote forms of Leishmania amazonensis, the causative agent of cutaneous leishmaniasis in humans. The essential oil of C. aschersoniana showed high activity against L. amazonensis promastigote forms $\left(\mathrm{IC}_{50}=4.46 \mu \mathrm{g} / \mathrm{mL}\right)$, however, it also demonstrated a relatively high cytotoxicity on mouse peritoneal macrophages $\left(\mathrm{CC}_{50}=7.71\right.$ $\mu \mathrm{g} / \mathrm{mL}$ ). This is the first report of the chemical composition and the leishmanicidal and cytotoxic activities of the leaf essential oil of $C$. aschersoniana.
\end{abstract}

Key words: Cryptocarya aschersoniana, Lauraceae, essential oil, Leishmania amazonensis, cytotoxic activity.

Correspondence to: Mayker Lazaro Dantas Miranda

E-mail: maykermiranda@iftm.edu.br 


\section{INTRODUCTION}

Leishmaniasis comprises a group of infectious diseases caused by parasites belonging to the Leishmania genus. This disease is among the six most important tropical diseases, affecting about 12 million people in 98 countries. It displays high endemicity, morbity and mortality, especially in Africa, Medium Orient, Latin America and Australia. In Brazil, leishmaniasis affects populations from 19 States, with predominance of rural transmission (Bastos et al. 2016).

The treatment of leishmaniasis is based on the pentavalent antimonials amphotericin B and pentamidines, which are toxic, expensive, difficult to administrate and can cause resistance in the parasites (Bastos et al. 2016, Estevam et al. 2017). It is clear therefore that the development of new antileishmanial agents has become an urgent matter. In this scenario, a number of papers have recently reported the antileishmanial potential of plant-derived essential oils (Bosquiroli et al. 2015, Oliveira et al. 2014).

Lauraceae is a botanical family known for comprising species of commercial interest due to their essential oils. The family includes approximately 50 genera and 2500 species. Among them, 400 species distributed in 25 genera are found in Brazil, with great incidence in the Amazon region (Yamaguchi et al. 2013). Published studies have described the chemical composition of Lauraceae essential oils as predominantly terpenes (Yamaguchi et al. 2013).

The genus Cryptocarya comprises about 350 species distributed mainly in Malaysia and Australia. Twenty-three species occur in South America and, among them, C. mandioccana, $C$. moschata, C. saligna and $C$. bothelhensis have already had the chemical composition of their essential oils previously identified (Telascrea et al. 2008). However, no reports were found in the literature on the chemical composition of the leaf essential oils of $C$. aschersoniana nor their antiLeishmania amazonensis and cytotoxic activities.

The species $C$. aschersoniana is popularly known in Brazil as canela-nhutinga, and is an important native species belonging to the ecological group of the shade tolerant climax species. It is a tree of 15 to $25 \mathrm{~m}$ of height that is distributed from Minas Gerais to Rio Grande do Sul and stands out mainly for its good quality wood, which favors its indiscriminate exploitation (Bonetti 2016, Tonetti et al. 2016).

Considering the interest in species of the family Lauraceae, the objective of this study was to describe, for the first time, the chemical composition and antileishmanial and cytotoxic activities of the leaf essential oil of Cryptocarya aschersoniana grown in the South of Minas Gerais.

\section{MATERIALS AND METHODS}

PLANT MATERIAL

Cryptocarya aschersoniana Mez. (Lauraceae) was collected in June 2016, in the municipality of Machado, State of Minas Gerais, Southeastern

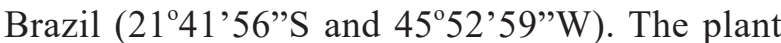
material was identified by the botanist Walnir G. F. Júnior. A voucher specimen (GERAES03) was deposited at the Herbário de Machado of the Departamento de Biologia, Instituto Federal de Educação, Ciência e Tecnologia do Sul de Minas Gerais, Brazil.

\section{EXTRACTION OF THE ESSENTIAL OIL}

Samples of fresh leaves of $C$. aschersoniana were subjected to hydrodistillation for 2 hours in a Clevenger-type apparatus (Carneiro et al. 2017). For the purpose of analysis, $300 \mathrm{~g}$ of plant material was divided into three samples of $100 \mathrm{~g}$ each, and $500 \mathrm{~mL}$ of distilled water was added to each sample. After manual collection of the essential oil (EO) samples, traces of remaining water in the oil was removed with anhydrous sodium sulfate, 
which was followed by filtration. The extraction procedure was done in triplicate. The isolated oil was stored under refrigeration until analyzed and tested. The yields $(\mathrm{w} / \mathrm{w})$ were calculated from the weight of the fresh leaves and expressed as the average of triplicate analysis.

\section{IDENTIFICATION OF THE ESSENTIAL OIL} CHEMICAL COMPOSITION

Gas chromatography (GC) analyses were performed on a Shimadzu GC2010 Plus gas chromatograph equipped with an AOC-20s autosampler and fitted with FID and a data-handling processor. An Rtx5 (Restek Co., Bellefonte, PA, USA) fused silica capillary column ( $30 \mathrm{~m}$ x 0.25-mm i.d. $0.25 \mu \mathrm{m}$ film thickness) was employed. The operation conditions were as follows: column temperature programmed to rise from 60 to $240{ }^{\circ} \mathrm{C}$ at $3{ }^{\circ} \mathrm{C} / \mathrm{min}$ and then held at $240{ }^{\circ} \mathrm{C}$ for $5 \mathrm{~min}$; carrier gas $=\mathrm{He}(99.999 \%)$, at $1.0 \mathrm{~mL} / \mathrm{min}$; injection mode; injection volume, 0.1 $\mu \mathrm{L}$ (split ratio of 1:10); and injector and detector temperatures $=240$ and $280{ }^{\circ} \mathrm{C}$, respectively. Components relative concentrations were obtained by peak area normalization (\%). The relative areas were the average of triplicate GC-FID analyses.

GC-MS analyses were carried out on a Shimadzu QP2010 Plus (Shimadzu Corporation, Kyoto, Japan) system equipped with an AOC$20 \mathrm{i}$ autosampler. The column was a RTX-5MS (Restek Co., Bellefonte, PA, USA) fused silica capillary column $(30 \mathrm{~m} \times 0.25 \mathrm{~mm}$ i.d. $\mathrm{x} 0.25 \mu \mathrm{m}$ film thickness). Electron ionization mode occurred at $70 \mathrm{eV}$, Helium (99.999 \%) was employed as the carrier gas at a constant flow of $1.0 \mathrm{~mL} / \mathrm{min}$. The injection volume was $0.1 \mu \mathrm{L}$ (split ratio of $1: 10$ ). The temperatures of the injector and the ionsource temperature were set at 240 and $280{ }^{\circ} \mathrm{C}$, respectively. The oven temperature program was the same as the program used for GC. Mass spectra were taken with a scan interval of $0.5 \mathrm{~s}$, in the mass range from 40 to $600 \mathrm{Da}$.
The identification of the volatile components from leaves of $C$. aschersoniana (Table I) was based on their retention indices on an Rtx-5MS capillary column under the same operating conditions as in the case of $\mathrm{GC}$ relative to a homologous series of $n$-alkanes $\left(\mathrm{C}_{8}-\mathrm{C}_{20}\right)$; structures were computermatched with the Wiley 7, NIST 08 and FFNSC 1.2 spectra libraries, and their fragmentation patterns were compared with literature data (Adams 1995).

\section{ANTILEISHMANIAL ASSAY}

In order to evaluate leishmanicidal activity, $L$. amazonensis promastigote forms (MHOM/BR/ PH8) were maintained in RPMI 1640 (Gibco) culture medium supplemented with $10 \%$ fetal bovine serum. Subsequently, about $1 \times 10^{6}$ parasites were distributed on 96-well plates. The essential oil was previously dissolved in 100\% dimethylsulfoxide (DMSO, stock solution $10 \mathrm{mg} \cdot \mathrm{mL}^{-1}$ (Synth)) and added to the cultures at concentrations from 1.56 to $50 \mu \mathrm{g} \cdot \mathrm{mL}^{-1}$. Amphotericin B was previously dissolved in $100 \%$ DMSO at concentration of $1 \mathrm{mg} \cdot \mathrm{mL}^{-1}$; afterwards, it was diluted in stock solution $500 \mu \mathrm{g} \cdot \mathrm{mL}^{-1}$ in the culture medium (Synth) and added to cultures at concentrations from 0.19 to $3.12 \mu \mathrm{g} \cdot \mathrm{mL}^{-1}$. Cultures were incubated at $25^{\circ} \mathrm{C}$ in BOD ovens (Quimis) for $24 \mathrm{~h}$ and the leishmanicidal activity was determined by growth inhibition of promastigote forms by counting the total number of live promastigotes in the Neubauer chamber (Global Glass, Porto Alegre, BR), considering flagellar motility. RPMI 1640 medium (Gibco) containing 0.5\% DMSO (Synth) (highest concentration) was used as negative control and Amphotericin B (Eurofarma, São Paulo, BR) at $1 \mu \mathrm{g} \cdot \mathrm{mL}^{-1}$ concentration was used as positive control. Results were expressed as the mean of the lysis percentage relative to the negative control (0.1\% DMSO). Two experiments were performed in triplicate. Determination of $50 \%$ inhibitory concentration values $\left(\mathrm{IC}_{50}\right)$ was carried 
out by non-linear regression curves of a GraphPad Prism version 5.0 Windows software (GraphPad software, USA). Maintenance of life cycle was approved by the Ethics Committee for Animal Care at the University of Franca, under protocol number 010/14.

\section{CYTOTOXICITY ASSAY}

In order to obtain the peritoneal macrophages, $\mathrm{BALB} / \mathrm{c}$. mice were intraperitoneally injected with $500 \mu \mathrm{L}$ of $3 \%$ sodium thioglycollate. After 72 hours, the mice peritonea were washed with $5 \mathrm{~mL}$ of ice-cold phosphate buffered saline (PBS $1 \mathrm{X})$, and the cells collected during washing were centrifuged at $1000 \mathrm{rpm}$ for 10 minutes at $4{ }^{\circ} \mathrm{C}$. The supernatant was removed and the pellet (cells) was added with $10 \mathrm{ml}$ of RPMI 1640 (Gibco) ice cold medium supplemented with $10 \%$ inactivated fetal bovine serum and $1 \%$ antibiotic $(10,000 \mathrm{U} / \mathrm{mL}$ penicillin and $10,000 \mathrm{mg} / \mathrm{mL}$ streptomycin).

The cells were counted in a Neubauer's chamber and adjusted to a concentration of $2 \mathrm{x}$ $10^{5}$ cells $/ \mathrm{mL}$. The cells were then seeded in a 96well plate with supplemented RPMI 1640 medium (Gibco).

The cultures were incubated at $37{ }^{\circ} \mathrm{C}$ in the presence of $5 \% \mathrm{CO}_{2}$ for 24 and 48 hours, and cell viability was determined by the colorimetric MTT metabolic activity assay [3-(4,5-dimethylthiazol2-yl)-2,5-diphenyltetrazolium bromide)], which assesses the ability of metabolically active cells to reduce MTT by converting their yellow salts to purple formazan crystals.

The essential oil was analyzed at the same concentrations as the assays on promastigote forms and the results were expressed as the mean percent reduction in cell viability versus the negative control (0.1\% DMSO). Experiments were performed in triplicate. The $50 \%$ cytotoxic concentration $\left(\mathrm{CC}_{50}\right)$ values were determined by means of non-linear regression curves using GraphPad Prism version
5.0 software for Windows (GraphPad software, USA).

\section{RESULTS AND DISCUSSION}

Thirty-four chemical constituents were identified in the leaf essential oil of $C$. aschersoniana, representing $97 \%$ of the total compounds. Table I shows these constituents including their respective retention indices, retention time and percentages.

The leaf essential oil of $C$. aschersoniana showed a high yield (w/w on fresh weight basis) of $3.5 \%$, similar to the previously observed yields for the essential oils of other species of the Lauraceae family. For example, yields of 4.9 and $2.5 \%$ for Endlicheria citriodora essential oils and 1.5\% for Aniba rosaeodora, which were considered high, are reported in the literature (Yamaguchi et al. 2013).

The analysis of $C$. aschersoniana leaf essential oil showed a complex mixture of monoterpenes and sesquiterpenes, with emphasis on monoterpene hydrocarbons (48.8\%), oxygenated monoterpenes (13.4\%) and oxygenated sesquiterpenes (26.7\%). The major constituents identified were: limonene (42.3\%), linalool (9.7\%) and nerolidol (8.6\%). The chemical composition observed in the present study was similar to the chemical composition already described in the literature for other species belonging to the same genus (Telascrea et al. 2008).

Similarly to what was found in the leaf essential oil of $C$. aschersoniana, the compounds limonene (42.3\%), linalool (9.7\%) and nerolidol (8.6\%) have previously been described as major constituents of the essential oils of three other species of the family Lauraceae; Litsea helferi, Litsea verticillata and Persea duthiei, which exhibited $17.5 \%$ of limonene, $23.4 \%$ of linalool and $13.2 \%$ of nerolidol (Le et al. 2014, Joshi et al. 2009). $\beta$-Caryophyllene $(0.3 \%)$, a common volatile metabolite among the essential oils of the Lauraceae family, was also found in the leaf essential oil of C. aschersoniana, but in a smaller quantity. 
TABLE I

Chemical composition of the leaf essential oil of $C$. aschersoniana (Lauraceae).

\begin{tabular}{|c|c|c|c|c|}
\hline$R T$ (min) & Compounds & $\boldsymbol{R} \boldsymbol{I}_{\text {exp }}$ & $\boldsymbol{R I}_{\text {lit }}$ & $R A \%$ \\
\hline 6.32 & Hex-3(Z)-en-1-ol & 858 & 857 & 1.5 \\
\hline 9.09 & $\alpha$-Pinene & 935 & 939 & 0.6 \\
\hline 10.94 & $\beta$-Pinene & 979 & 980 & 0.9 \\
\hline 13.21 & $p$-Cymene & 1030 & 1029 & 4.6 \\
\hline 13.34 & Limonene & 1033 & 1034 & 42.3 \\
\hline 13.45 & Eucalyptol & 1035 & 1035 & 0.8 \\
\hline 14.75 & $\gamma$-Terpinene & 1063 & 1062 & 0.4 \\
\hline 16.20 & trans-Linalool oxide & 1095 & 1093 & 1.8 \\
\hline 17.04 & Linalool & 1112 & 1110 & 9.7 \\
\hline 20.36 & trans-Pyranoid linalool oxide & 1179 & $1178^{\mathrm{a}}$ & 0.3 \\
\hline 20.49 & Terpinen-4-ol & 1181 & 1180 & 0.3 \\
\hline 26.07 & Limonene dioxide & 1302 & $1300^{\mathrm{b}}$ & 0.5 \\
\hline 29.44 & $\alpha$-Copaene & 1378 & 1376 & 0.5 \\
\hline 29.52 & $\beta$-Elemene & 1379 & 1379 & 0.7 \\
\hline 30.31 & $\beta$-Cubebene & 1398 & 1397 & 1.0 \\
\hline 31.01 & $\beta$-Caryophyllene & 1414 & 1415 & 0.3 \\
\hline 32.12 & Aromadendrene & 1441 & 1439 & 0.7 \\
\hline 33.67 & Gemacrene D & 1479 & 1480 & 0.6 \\
\hline 33.87 & $\alpha$-Amorphene & 1485 & $1485^{\mathrm{c}}$ & 1.3 \\
\hline 34.09 & $\beta$-Selinene & 1490 & 1489 & 0.5 \\
\hline 34.25 & $\delta$-Selinene & 1494 & $1495^{\mathrm{d}}$ & 0.4 \\
\hline 34.64 & Viridiflorene & 1504 & 1505 & 1.0 \\
\hline 35.17 & $\gamma$-Cadinene & 1518 & 1518 & 0.4 \\
\hline 35.53 & $\delta$-Cadinene & 1527 & 1525 & 0.8 \\
\hline 36.01 & Hedycaryol & 1539 & $1538^{\mathrm{e}}$ & 0.5 \\
\hline 37.30 & Nerolidol & 1573 & 1572 & 8.6 \\
\hline 37.72 & Spathulenol & 1583 & 1584 & 6.6 \\
\hline 37.88 & Isoaromadendrene epoxide & 1588 & 1585 & 0.8 \\
\hline 38.53 & Guaiol & 1605 & 1604 & 2.5 \\
\hline 38.78 & Globulol & 1612 & 1610 & 0.5 \\
\hline 39.34 & $\delta$-Cadinol & 1627 & $1628^{\mathrm{f}}$ & 1.2 \\
\hline 39.65 & Cubenol & 1636 & 1637 & 0.4 \\
\hline 40.64 & $\alpha$-Cadinol & 1663 & 1663 & 2.5 \\
\hline \multirow[t]{7}{*}{41.11} & Bulnesol & 1676 & 1675 & 1.5 \\
\hline & Monotepene hydrocarbons & & & 48.8 \\
\hline & Oxygenated monoterpenes & & & 13.4 \\
\hline & Sesquiterpene hydrocarbons & & & 8.2 \\
\hline & Oxygenated sesquiterpenes & & & 25.1 \\
\hline & Others & & & 1.5 \\
\hline & Total & & & 97.0 \\
\hline
\end{tabular}

RT: Retention time; $\boldsymbol{R I}_{\text {exp }}$ : Retention index determined relative to $n$-alkanes $\left(\mathrm{C}_{8}-\mathrm{C}_{20}\right)$ on the Rtx-5MS column; $\boldsymbol{R I}_{\text {lit }}$ : Retention index from literature (Adams 1995); $\boldsymbol{R} \boldsymbol{A} \%$ : relative area (peak area relative to the total peak area in the GC-FID chromatogram), average of three replicates. ${ }^{a}$ from Boulanger and Crouzet (2000); ${ }^{b}$ from Hognadóttir and Rouseff (2003); ${ }^{\text { }}$ from Karioti et al. (2003); ${ }^{\mathrm{d}}$ from Albuquerque et al. (2004); ${ }^{\mathrm{e}}$ from Bin Ahmad and Bin Jantan (2003); ${ }^{\mathrm{f}}$ from Hamm et al. (2005). 
Linalool (9.7\%), an important constituent found in essential oils of several species of Lauraceae, deserves special attention. This openchain tertiary monoterpene alcohol has been successfully applied as sedative, anticonvulsant and also has wide application in the fragrance and flavor industry (Monteiro et al. 2005).

The leishmanicidal potential of essential oils has been well studied (Cardoso et al. 2015), and the leaf essential oil of $C$. aschersoniana displayed high leishmanicidal activity when tested against L. amazonensis promastigote forms. Increase in parasite lysis was observed with increase in essential oil concentration, with $\mathrm{IC}_{50}=4.46 \mu \mathrm{g} / \mathrm{mL}$ (Table II). The leaf essential oil of $C$. aschersoniana inhibited parasite growth in a concentration/dose-dependent manner. As positive control was used amphotericin $\mathrm{B}\left(\mathrm{IC}_{50}=1.88 \mu \mathrm{g} / \mathrm{mL}\right)$, an antifungal with broad spectrum of action that is used as second-line drug against leishmaniasis and that show a high toxicity in the host (Bastos et al. 2016, Fernández-García et al. 2017).

Regarding the leishmanicidal activity ( $\mathrm{IC}_{50}$ values), the literature describes that samples having $\mathrm{IC}_{50}<10 \mu \mathrm{g} / \mathrm{mL}$ are considered highly active, $\left(\mathrm{IC}_{50}\right.$ $>10<50 \mu \mathrm{g} / \mathrm{mL}$ ) active, $\left(\mathrm{IC}_{50}>50<100 \mu \mathrm{g} / \mathrm{mL}\right.$ ) moderately active, and ( $\left.\mathrm{IC}_{50}>100 \mu \mathrm{g} / \mathrm{mL}\right)$ inactive (de Lima et al. 2012).

The high leishmanicidal activity of the essential oil from leaves of $C$. aschersoniana may be related to the presence of the chemical components limonene (42.3\%), linalool (9.7\%) and nerolidol $(8.6 \%)$, which are the major constituents in the essential oil studied and with anti-Leishmania activity already known (Arruda et al. 2005, Graebin et al. 2010, Camargo and Vasconcelos 2014). Limonene has also been previously reported as the compound responsible for the leishmanicidal activity exhibited by the essential oils of Citrus limonia and Citrus latifolia (Estevam et al. 2016). The leishmanicidal potential of the linalool was already reported in the literature against promastigote and amastigote forms of $L$. amazonensis $\left(\mathrm{LD}_{50}\right.$ of $4.3 \mathrm{ng} / \mathrm{mL}$ and $15.5 \mathrm{ng} /$ $\mathrm{mL}$, respectively) (Camargo and Vasconcelos 2014). Nerolidol, in turn, showed promising leishmanicidal activity against the promastigote forms of Leishmania amazonensis, L. braziliensis, and L. chagasi (Arruda et al. 2005). The treatment of macrophages infected by $L$. amazonensis with $100 \mu \mathrm{M}$ of nerolidol resulted in $95 \%$ reduction in infection rates (Arruda et al. 2005). However, further studies should be addressed to verify the occurrence of possible synergistic and/or additive effects between these compounds.

The in vitro cytotoxic activity of the $C$. aschersoniana leaf essential oil and the drug amphotericin B against peritoneal macrophages is shown in Table III.

This is the first report of the cytotoxic activity of the leaf essential oil of $C$. aschersoniana. The oil evaluated in this study showed high toxicity to

TABLE II

Leishmanicidal activity of the leaf essential oil of $C$. aschersoniana against $L$. amazonensis promastigote forms.

\begin{tabular}{cccccccc}
\hline & \multicolumn{4}{c}{$\%$ of lysis \pm S.D $/$ Concentration $\left(\boldsymbol{\mu g} . \mathbf{m L}^{-\mathbf{1}}\right)$} & \multicolumn{2}{c}{$\mathrm{IC}_{\mathbf{5 0}}(\boldsymbol{\mu g} / \mathbf{m L})$} \\
\cline { 2 - 8 } & $\mathbf{1 0 0}$ & $\mathbf{5 0}$ & $\mathbf{2 5}$ & $\mathbf{1 2 . 5}$ & $\mathbf{6 . 2 5}$ & $\mathbf{3 . 1 2}$ & \\
\hline \multirow{2}{*}{ EOCA } & $100 \pm 0.00$ & $100 \pm 0.00$ & $97.86 \pm 1.88$ & $72.68 \pm 1.48$ & $52.96 \pm 1.88$ & $45.60 \pm 1.48$ & 4.46 \\
\hline \multirow{2}{*}{ Amph. B } & 50 & 25 & 12.5 & 6.25 & 3.12 & 1.56 & \\
& $100 \pm 0.00$ & $99.98 \pm 0.10$ & $96.15 \pm 0.54$ & $85.84 \pm 0.24$ & $80.78 \pm 0.29$ & $75.5 \pm 0.57$ & 1.88 \\
\hline
\end{tabular}

EOCA: Leaf essential oil of Cryptocarya aschersoniana. Negative Control: RPMI Medium $+0.1 \%$ DMSO. Amph. B: Amphotericin B. 
TABLE III

Cytotoxicity of the leaf essential oil of $C$. aschersoniana and Amphotericin B.

\begin{tabular}{|c|c|c|c|c|c|c|}
\hline & \multicolumn{5}{|c|}{ Concentrations $(\mu \mathrm{g} / \mathrm{mL}) \pm$ Standard Deviation } & \multirow{2}{*}{$\mathrm{CC}_{50}(\mu \mathrm{g} / \mathrm{mL})$} \\
\hline & 50 & 25 & 12.5 & 6.25 & 3.12 & \\
\hline EOCA & $84.53 \pm 2.68$ & $84.32 \pm 4.24$ & $80.70 \pm 7.80$ & $36.62 \pm 6.13$ & $13.86 \pm 3.85$ & 7.71 \\
\hline Amph. B & $52.54 \pm 3.04$ & $51.44 \pm 1.90$ & $50.64 \pm 2.21$ & $19.76 \pm 0.08$ & $9.73 \pm 0.38$ & 51.86 \\
\hline
\end{tabular}

EOCA: Leaf essential oil of Cryptocarya aschersoniana. Amph. B: Amphotericin B. Positive control: 25.0\% DMSO; Negative control: $0.1 \%$ DMSO.

mouse peritoneal macrophages $\left(\mathrm{CC}_{50}=7.71 \mu \mathrm{g}\right.$ / $\mathrm{mL}$ ), while the drug amphotericin $\mathrm{B}$ was less toxic $\left(\mathrm{CC}_{50}=51.86 \mu \mathrm{g} / \mathrm{mL}\right)$. Toxicity levels are reported in the literature as highly toxic $\mathrm{CC}_{50}<10 \mu \mathrm{g} / \mathrm{mL}$, toxic $\left(10<\mathrm{CC}_{50}<100 \mu \mathrm{g} / \mathrm{mL}\right)$, moderately toxic $\left(100<\mathrm{CC}_{50}<1000 \mu \mathrm{g} / \mathrm{mL}\right)$, and nontoxic $\left(\mathrm{CC}_{50}>\right.$ $1000 \mu \mathrm{g} / \mathrm{mL}$ ) (de Lima et al. 2012).

Evaluation of cytotoxicity is important because it allows us to understand the biological mechanism that produces the cytotoxic effect and the mechanism of action of different substances in their interaction with tissues. However, it is recognized that the use of cell cultures is not physiological and does not replicate the actual architecture of the living tissue in which the underlying cells could repair the aggressions suffered. Thus, the occurrence of in vitro cytotoxic effect does not guarantee that the evaluated sample is toxic when applied in vivo (Marreiro et al. 2014).

In summary, the strong anti-Leishmania amazonensis activity and cytotoxicity observed for the leaf essential oil of $C$. aschersoniana can be explained by the fact that most of the leaf essential oil contains a large number of compounds that have no specific cellular targets. Essential oils have non-polar character and can easily cross the cell walls and cytoplasmic membranes (Estevam et al. 2018). Thus, essential oil components cross the membrane, cause the cytoplasm to coagulate, denature proteins, disrupt metabolic pathways such as biosynthesis of various lipids, and ultimately lead to cell death through necrosis and apoptosis (Raut and Karuppayil 2014).

The results in this study show that the leaf essential oil of $C$. aschersoniana has strong antiLeishmania amazonensis activity and high toxicity against mouse peritoneal macrophages. Previous studies on the leishmanicidal potential of some of the chemical constituents identified in the essential oil of $C$. aschersoniana also corroborate the potential observed in the present investigation. However, further in vivo studies are needed to confirm and evaluate the potential use of the leaf essential oil of C. aschersoniana as a leishmanicidal agent.

\section{REFERENCES}

ADAMS RP. 1995. Identification of Essential Oil Components by Gas Chromatography/Quadrupole Mass Spectroscopy. Allured Publishing Corporation: Carol Stream, 469 p.

ALBUQUERQUE MRJR, SILVEIRA ER, UCHOA DEA, LEMOS TLG, SOUZA EB, SANTIAGO GMP AND PESSOA ODL. 2004. Chemical composition and larvicidal activity of the essential oils from Eupatorium betonicaeforme (D.C.) Baker (Asteraceae). J Agric Food Chem 52: 6708-6711.

ARRUDA DC, D'ALEXANDRI FL, KATZIN AM AND ULIANA SRB. 2005. Antileishmanial activity of the terpene nerolidol. Antimicrob Agents Chemother 49: 1679-1687.

BASTOS MM, BOECHAT N, HOELZ LVB AND OLIVEIRA AP. 2016. Quimioterapia antileishmania: uma revisão da literatura. Rev Virtual Quim 8: 2072-2104.

BIN AHMAD F AND BIN JANTAN I. 2003. Chemical constituents of the essential oils of Goniothalamus uvariodes King. Flavour Fragr J 18: 128-130.

BONETTI KAP. 2016. Lauraceae em parques ecológicos de São Bento do Sul, SC. Saúde Meio Ambiente 5: 54-62. 
BOSQUIROLI LSS, DEMARQUE DP, RIZK YS, CUNHA MC, MARQUES MCS, MATOS MFC, KADRI MCT, CAROLLO CA AND ARRUDA CCP. 2015. In vitro antiLeishmania infantum activity of essential oil from Piper angustifolium. Braz J Pharmacog 25: 124-128.

BOULANGER R AND CROUZET J. 2000. Free and bound flavour components of Amazonian fruits: 3-glycosidically bound components of cupuacu. Food Chem 70: 463-470.

CAMARGO SB AND VASCONCELOS DFSA. 2014. Biological activities of linalool: current concepts and future possibilities of this monoterpene. Rev Cienc Med Biol 13: 381-387.

CARDOSO BM ET AL. 2015. Antileishmanial activity of the essential oil from Tetradenia riparia obtained in different seasons. Mem Inst Oswaldo Cruz 110: 1024-1034.

CARNEIRO NS, ALVES JM, ALVES CCF, ESPERANDIM VR AND MIRANDA MLD. 2017. Óleo essencial das flores de Eugenia klotzschiana (Myrtaceae): composição química e atividades tripanocida e citotóxica in vitro. Rev Virtual Quim 9: 1381-1392.

DE LIMA JPS, PINHEIRO MLB, SANTOS AMG, PEREIRA JLS, SANTOS DMF, BARISON A, SILVA-JARDIM I AND COSTA EV. 2012. In vitro antileishmanial and cytotoxic activities of Annona mucosa (Annonaceae). Rev Virtual Quim 4: 692-702.

ESTEVAM EBB ET AL. 2016. Composição química e atividades biológicas dos óleos essenciais das folhas frescas de Citrus limonia Osbeck e Citrus latifolia Tanaka (Rutaceae). Rev Virtual Quim 8: 1842-1854.

ESTEVAM EBB ET AL. 2017. In vitro antiparasitic activity and chemical composition of the essential oil from Protium ovatum leaves (Burceraceae). An Acad Bras Cienc 89: 3005-3013.

ESTEVAM EBB, ALVES CCF, ESPERANDIM VR, CAZAL CM, SOUZA AF AND MIRANDA MLD. 2018. Chemical composition, anti-Trypanosoma cruzi and cytotoxic activities of the essential oil from green fruits of Protium ovatum (Burseraceae). Rev Bras Frutic 40: e-794.

FERNÁNDEZ-GARCIA R, DE PABLO E, BALLESTEROS MP AND SERRANO DR. 2017. Unmet clinical needs in the treatment of systemic fungal infections: the role of amphotericin B and drug targeting. Int J Pharm 525: 139148.

GRAEBIN CS, MADEIRA MF, YOKOYAMA-YASUNAKA JKU, MIGUEL DC, ULIANA SRB, BENITEZ D, CERECETTO H, GONZÁLEZ M, ROSA RG AND EIFLER-LIMA VL. 2010. Synthesis and in vitro activity of limonene derivatives against Leishmania and Trypanosoma. Eur J Med Chem 45: 1524-1528.

HAMM S, BLETON J, CONNAN J AND TCHAPLA A. 2005. A chemical investigation by headspace SPME and
GC-MS of volatile and semi-volatile terpenes in various olibanum samples. Phytochem 66: 1499-1514.

HOGNADÓTTIR A AND ROUSEFF RL. 2003. Identification of aroma active compounds in orange essence oil using gas chromatography-olfactometry and gas chromatographymass spectrometry. J Chromatogr A 998: 201-211.

JOSHI SC, PADALIA RC, BISHT DS AND MATHELA CS. 2009. Terpenoid diversity in the leaf essential oils of Himalayan Lauraceae species. Chem Biodivers 6: 13641373.

KARIOTI A, SKALTSA H, DEMETZOS C, PERDETZOGLOU D, ECONOMAKIS CD AND SALEM AB. 2003. Effect of nitrogen concentration of the nutrient solution on the volatile constituents of leaves of Salvia fruticosa Mill. in solution culture. J Agric Food Chem 51: 6505-6508.

LE CS, DO ND, TRAN DT, DUONG DH AND ISIAKA AO. 2014. Analysis of the essential oils from five Vietnamese Litsea species (Lauraceae). J Essent Oil Bearing Plants 17: 960-971.

MARREIRO RO, BANDEIRA MFCL, ALMEIDA MC, COELHO CN, VENÂNCIO GN AND CONDE NC. 2014. Cytotoxicity evaluation of a mouthwash containing extract of Libidibia ferrea. Pesq Bras Odontoped Clin Integr 14: 34-42.

MONTEIRO SS, SIANI AC, GARRIDO IS, RAMOS MCKV AND AQUINO-NETO FR. 2005. Chemical variability and optical resolution of linalool in the essential oil of Aeollanthus suaveolens (Lamiaceae). Rev Fitos 1: 58-63.

OLIVEIRA ESC, AMARAL ACF, LIMA ES AND SILVA JRA. 2014. Chemical composition and biological activities of Bocageopsis multiflora essential oil. J Essent Oil Res 26: 161-165.

RAUT JS AND KARUPPAYIL SM. 2014. A status review on the medicinal properties of essential oils. Ind Crops Prod 62: 250-264.

TELASCREA M, ARAÚJO CC, CAVALHEIRO AJ, MARQUES MOM, FACANALI R AND MORAES PLR. 2008. Essential oils from leaves of Cryptocarya spp. from the atlantic rain forest. Quim Nova 31: 503-507.

TONETTI OAO, FARIA JMR, JOSÉ AC, OLIVEIRA TGS AND MARTINS AJC. 2016. Seed survival of the tropical tree Cryptocarya aschersoniana (Lauraceae): consequences of habitat disturbance. Austral Ecology 41: 248-254.

YAMAGUCHI KKL, VEIGA-JUNIOR VF, PEDROSA TN, VASCONCELLOS MC AND LIMA ES. 2013. Biological activities of essential oil of Endlicheria citriodora, a methyl geranate - rich Lauraceae. Quim Nova 36: 826830. 